\title{
COVID-19: PROLONGED VIRAL SHEDDING IN AN HIV PATIENT WITH LITERATURE REVIEW OF RISK FACTORS FOR PROLONGED VIRAL SHEDDING AND ITS IMPLICATIONS FOR ISOLATION STRATEGIES
}

\author{
Muhammad Yousaf ${ }^{1}$, Mansoor Hameed ${ }^{1}$, HUSSAM ALSOUB ${ }^{1}$, Mohamad Khatib ${ }^{1}$, Wasim \\ Jamal $^{1}$, and Mushtaq Ahmad ${ }^{1}$ \\ ${ }^{1}$ Hamad Medical Corporation
}

November 5, 2020

\begin{abstract}
We present prolonged viral shedding in an immunocompromised HIV patient with a literature review of risk factors for prolonged viral shedding and its implications for isolation strategies. We explore the role of PCR-CT-value (cycle threshold) as an instrument for guiding isolation policies and the impact of HIV on Covid-19.
\end{abstract}

\section{Hosted file}

Covid-19 HIV Viral shedding.pdf available at https://authorea.com/users/373253/articles/ 490998-covid-19-prolonged-viral-shedding-in-an-hiv-patient-with-literature-review-ofrisk-factors-for-prolonged-viral-shedding-and-its-implications-for-isolation-strategies 


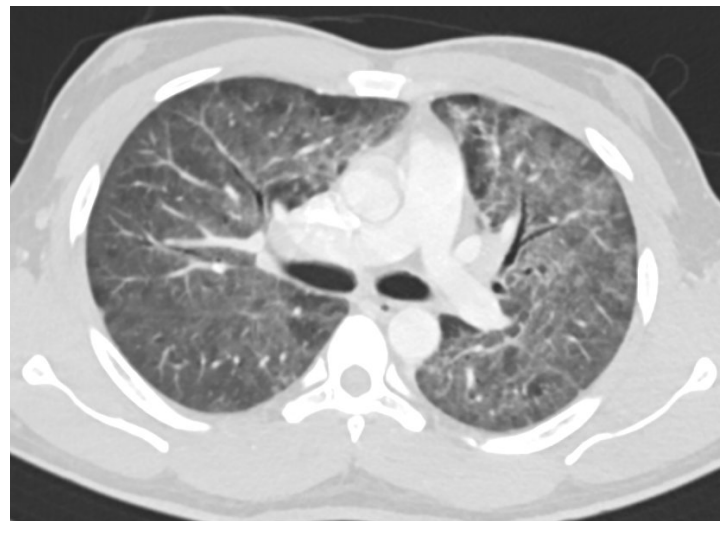

